\title{
Attitudes towards Thai English: Indonesian Pre- service Teachers Lenses During Teaching Practicum in Thailand
}

\author{
Firda Fauziyah', Arini Nurul Hidayati², Fuad Abdullah3
}

DOI: 10.35445/alishlah.v13i3.809

\section{Article Info}

Keywords:

Thai English;

Pre-service teachers;

Teaching Practicum

Kata kunci:

Thai English;

Guru praktikan;

Praktik mengajar

\section{Abstract}

Over the last few decades, World Englishes have shifted the paradigm of how both native and non-native speakers view English as a lingua franca. This paradigmatic shift has attracted scholars to conduct a plethora of investigations on the roles of English as an international language. However, scrutinizing the pre-service teachers' attitudes towards Thai English amid their teaching practicum in Thailand remains under-explored, notably viewed from Indonesian perspectives. This study investigated Indonesian pre-service teachers' attitudes towards Thai English within their teaching practicum in Thailand to fill this gap. Four Indonesian pre-service teachers performing teaching practicum at diverse Thai schools were recruited as the participants. The data were garnered through semi-structured interviews and analyzed with qualitative data analysis framework. The findings revealed that Thai English was less intelligible. Besides, they contended that Thai English enables them to experience emotional shifts. Eventually, Thai English has adapted from the English and Thai language. With these in mind, understanding and employing Thai English practically offers the Indonesian pre-service teachers another variety of English to communicate in the classroom.

\begin{abstract}
Abstrak
Selama beberapa dekade terakhir, Bahasa Inggris Dunia (World Englishes) telah mengubah paradigma tentang bagaimana penutur asli dan penutur asing bahasa Inggris memandang bahasa Inggris sebagai lingua franca. Pergeseran paradigma ini telah menarik para ilmuan untuk melakukan sejumlah penelitian tentang peran bahasa Inggris sebagai bahasa internasional. Namun, penelitian mengenai sikap guru praktikan terhadap Bahasa Inggris Thailand di tengah praktik mengajar mereka di Thailand masih kurang dieksplorasi, terutama dilihat dari perspektif guru praktikan Indonesia. Untuk mengisi kesenjangan ini, penelitian ini bertujuan untuk menyelidiki sikap-sikap guru praktikan Indonesia terhadap Bahasa Inggris Thailand selama praktik mengajar mereka di Thailand. Empat guru praktikan Indonesia yang melakukan praktik mengajar di sejumlah sekolah Thailand direkrut sebagai peserta. Data dikumpulkan melalui wawancara semi terstruktur dan dianalisis dengan kerangka analisis data kualitatif. Temuan mengungkapkan bahwa bahasa Inggris Thai kurang dimengerti. Selain itu, mereka berpendapat bahwa bahasa Inggris Thai memungkinkan mereka mengalami perubahan emosi. Yang terakhir, bahasa
\end{abstract}

\footnotetext{
${ }^{1}$ Universitas Siliwangi, Tasikmalaya, Indonesia Email: firdafauziyahh@gmail.com 2 Universitas Siliwangi, Tasikmalaya, Indonesia Email: arininurul@unsil.ac.id 3 Universitas Siliwangi, Tasikmalaya, Indonesia Email: fuad.abdullah183@gmail.com
} 
Inggris Thai merupakan adaptasi dari bahasa Thai dan bahasa Inggris. Berdasarkan hal tersebut, memahami dan menggunakan Bahasa Inggris Thai secara praktis menawarkan kepada para guru prajabatan Indonesia variasi bahasa Inggris yang berbeda untuk berkomunikasi di dalam kelas.

\section{INTRODUCTION}

The advanced development of globalization has spread English throughout the world rapidly and reshaped the dynamic of English. As a result, the number of 'non-native speakers' of English increased significantly over the 'native speakers.' In 2003, it was estimated that there were 320-380 million English native speakers, 300 to 500 million English as second language speakers, and 500 million to one billion nonnative English speakers (Crystal 2003, as cited in Curran \& Chren, 2017). This indicates that English is used as a communication tool among native speakers of English and English non-native speakers. Since the beginning of the nineteenth century, Britain and the USA had sent English by economic and political imperialism (Crystal, 2012). In particular, Asian countries put English as a subject in educational settings (Curran and Chern, 2017). This implies that many Asian countries consider English as an essential role in their education systems.

Regarding the division of English usage across the globe, Kachru (1985), as cited in Al-Mutairi (2019), introduced three concentric circles: the inner circle (countries where English is used as a native language), the outer circle (countries that have old historical British colonial relations and use English for communicational, institutional, and official purposes), and the expanding circle (the rest of the world where the spread of English has reached) to show that no superior variety of English and as the fundamental for respecting English varieties. These diverse areas have been shaped differently, which affect various responses by other speakers from different circles. This could bring both positive or negative attitudes towards English and its users.

Thailand belongs to the expanding circle in the English spread classification by Kachru (1985), which indicates that Thailand has no history of colonization by British and English is taught as a foreign language (EFL) and used for communication, particularly with foreigners (Sarmah, Gogoi, \& Wiltshire, 2009). In addition, the use of English in Thailand is frequently utilized for personal interests such as travel, socialization, and enjoyment. Hence, English is generally used as an international lingua franca (Trakulkasemsuk, 2018). Moreover, the 'Thai English' term has been used in several studies recently (Watkhaolarm; Sarmah et al., 2009; 2005Kim, 2018).

Few distinctive characteristics found in Thai English which shifted from their first language background, culture, rhetorical style, and norm of communication, thus Thai speakers use English as their way in presenting their identity (Trakulkasemuk, 2012; Abdullah \& Lulita, 2018). The distinctive features of Thai English gathered from written data and phonological features. Distinctive features of Thai English obtained from autobiography as the literature written in English by a native Thai has been explored by Watkhaolarm (2005). He mentioned that language contact processes that affect Thai English are transfer, translation, shift, lexical borrowing, and hybridization. Transfer shifted the social and cultural element into English. An example of a cultural element is 'Cousin Chinn'; they use the term of kinship with names. The social element addresses people buying titles, birth rank, and social status, such as Kroo Nil, Kroo means teacher. Translation features found are very common in Thai literature. Translation from Thai into English leads to a different collocation from native English writing. For instance, The Abbot was pleased with Father's service; he often referred to him as "white elephant from the jungle." (p. 149). In Thai Buddhism, a white elephant is related to the ability to attract such divine beings. Meanwhile, the Thai writer shifts a Thai writing style to English. This feature uses Thai proverbs and old sayings. An example of the shift is that His folks used to tell their children that if someone stole food after he died and been reborn, his mouth would be as small as a needle hole. Regarding lexical borrowing, it is used to give authenticity. Moreover, lexical borrowing is also followed by translation to clarify the story: 'Friday is the annual Poy Tai Kwa Suk ceremony at Homong, and Khun Sa has asked me to invite you and Mandy to 
attend." "Jimmy, I know Burmese, but I don’t know what ceremony you're talking about," Mandy interrupted. "It means 'sending the brave ones off to battle' in the Shan language," replied Jimmy (p. 153). The last is hybridization. There are Thai terms of hybridized items. For example, the term "farang" is used for Caucasian or something Western.

Furthermore, the investigation of phonological features of Thai English was conducted by Tsukada (2008). He explored the comparison of phonetic characteristics of English vowels, four monophthongs, / I $\mho \wedge æ /$, and two diphthongs /eı ov/ spoken by Australian English speakers and Thai English speakers lived in Australia for an average of 3.2 years. The results showed no significant difference between the Australian speakers for monophthongs in terms of vowel quality, proven by formant measurement. Nonetheless, the distinctive difference found in their production of diphthongs, Thai speakers associated the English diphthongs /er ov/ with the long / e: o:/. In the further study, Tsukada (2009) expands the monophthongs /I/ and /i/ used by Thai speakers in terms of the duration. The words chosen are beep, beat, beak, feet, seep, seat, seek for /i/, kit, kick, lip, lit, lick, sip, sit, sick for /I/. The study highlighted different durational differentiation between /I/ and /i/ for Australian and Thai speakers. Thai speakers produced /I/ shorter than Australian speakers do; contrastively, vowel /i/ produced longer. Although Thai English speakers produced dissimilarity with Australian speakers, it did not lead the pronunciation of Thai English to become unintelligible for other speakers. It only might lead the Thai English speakers to sound distinct and foreign to the speakers of native English (Trakulkasemuk, 2012; Andriani \& Abdullah, 2017).

The great distinguishing feature of Thai English lies in the consonants. In the pronunciation of Thai English speakers, the consonants sound significantly different since there are numerous English consonants not produced in Thai, and even Thai speakers replace the consonants with the ones that exist in Thai (Trakulkasemuk, 2012). The main distinctive characteristic in pronunciation of English consonants in Thai English has been discussed by Kuatracue (1960), as cited in Trakulkasemuk, 2012). He stated that English consonants such as $/ \mathrm{t} / /, / \theta /, / \partial /, / \mathrm{J} /, / \mathrm{d} 3 /, / 3 /$, do not exist in Thai. "Therefore, $/ \mathrm{t} \mathrm{f} /, / \mathrm{J} /$ and $/ 3 /$ are normally found substituted by Thai $/ \mathrm{tc}$ / ". "Also, Thai speakers usually substitute the Thai consonants $/ \mathrm{t} /, / \mathrm{t}^{\mathrm{h}} /$, or $/ \mathrm{s} /$, for $/ \theta /$ ". Afterward, in Thai English, /d/ is used for /ð/. Furthermore, "/v/ is usually substituted with /w/ and /z/ with /s/. To sum up, Thai English has unique features that distinguish it from other English varieties. These distinctive features would impact diverse attitudes performed by people interacting with its users, specifically international teachers teaching in Thailand.

In the field of study, there were Indonesian English pre-service teachers from one state university in Indonesia joining the international teaching practicum (ITP) program in southern Thailand for five months. They encountered the fact that they communicated and worked with individuals from different cultural backgrounds. However, the former issue found that the Indonesian English pre-service teachers assumed Thai English was 'funny' and 'weird'. Underpinning this preliminary assumption, this study explores the Indonesian English pre-service teachers' attitudes toward Thai English to understand better how they behave when communicating with Thai English users during the ITP program. Theoretically, the term 'attitude' in this context refers to the concept coined by Triandis (1971) as cited in Dwyer (1993, p.2), noting that attitude has three "components: (a) a cognitive component (the idea or beliefs), (b) an effective component (the emotions), and (c) a behavioral component (the action)." Attitude, therefore, is defined in three components, first is the cognitive component as the ideas and beliefs that pre-service teachers have about the English speakers. The second is the affective component, which refers to feelings owned by pre-service teachers when they interact or hear their students speak English. Lastly, the behavioral component deals with the action (Hidayati, Dewi, Nurhaedin, \& Rosmala, 2020) in how pre-service teachers act or react to English speakers.

Even though a plethora of studies have accentuated English as a lingua franca (e.g., Jenkins, 2007; Jenkins, Cogo, \& Dewey; 2011; Taguchi \& Ishihara, 2018; Hidayati \& Santiana, 2020; Wang, 
Jiang, Fang \& Elyas, 2021), World Englishes (e.g., Kachru, 1992; Kachru, \& Nelson, 2006; Marlina, 2017; Lim, 2020; Hamid, Hoang \& Nguyen, 2021), insufficient attention has been given to Thai English (e.g., Sirivedin, Soopunyo, Srisuantang \& Wongsothorn, 2018; Rajprasit, 2021). Moreover, the topic of English teachers' attitudes toward English varieties has gathered researchers' attention in the past decade (Ahn, 2014, 2015; Curran \& Chern, 2017; Sadeghpour \& Sharifian, 2017; Sa'd, 2018; Lee, Lee, \& Drajati, 2019; Rezaei, Khosravizadeh, \& Mottaghi, 2019). From the pre-services' perspective, Ahn (2015) examined Korean and English teachers' attitudes toward Asian English varieties (Singaporean, Indian, Chinese, and Japanese English). The result showed that the lack of awareness of four selected Asian Englishes led to the teachers' rejection and negative attitude towards those Asian Englishes. The study concerning students' attitudes toward English varieties (British, American, African American Vernacular, Persian, and Australian English) has been pointed out by Rezaei, Khosravizadeh \& Mottaghi (2018). However, a few studies documented pre-service English teachers' attitudes toward English varieties along with Thai English. In particular, it lays a gap of empirical research on attitudes toward English varieties taking part during international teaching Practicum. Even none of the empirical scrutinies focuses on the Indonesian pre-service teachers' cognition, affection, and behavior towards Thai English. Against this background, the present study aims at probing the Indonesian pre-service teachers' attitudes towards Thai English amid their teaching practicum in Thailand.

Pedagogically speaking, the current investigation attempts to extend the scholarship in World Englishes, notably Thai English as an English variety, from the Indonesian educational perspective. Likewise, this scrutiny provides insights and opens new minds that Thai English is a representation of English variety accommodating diversities of its speakers' backgrounds (e.g. identity, culture, ideology and socio-history), particularly English teachers to develop contextual teaching materials, choose an appropriate assessment mechanism and instruments and generate the students' awareness on assorted cultural identities, faith traditions and current practices of English speakers around the world. More importantly, the present study leads non-native speakers to consider English as a heterogeneous global language rather than an exclusive language of its native speakers (native speakers).

\section{METHODS}

A descriptive case study was chosen as the design of this qualitative scrutiny. The participants of this study were four Indonesian English pre-service teachers from one of the state universities in Indonesia who had joined an international teaching practicum (ITP) program in four different schools in Nakhon Si Thammarat Province and Krabi Province, southern Thailand, for five months. There were two males and two females with an age range between 21-22 years old. Their cognitive intelligence was relatively high, proven by the GPA ranging from $3.47-3.99$ out of 4.00. The data was collected from semi-structured interview since it was designed to ensure subjective responses from the participants regarding a particular phenomenon that they had experienced, and it also could make the participants feel free to answer the whole questions given related to their own experience (McIntosh \& Morse, 2015; ). The questions were divided into three aspects. The first aspect was to investigate participants' cognitive attitudes. The second aspect was made to investigate affective attitude. The third aspect was designed to investigate participants' behavioural attitudes. The interviews were conducted from $25^{\text {th }}-30^{\text {th }}$ of March 2020 by WhatsApp voice recorder and reconfirmed via the WhatsApp text feature. After collecting the data, it was furthermore analysed and analyzed using the data analysis method by Miles, Huberman, \& Saldaña (2014). The framework employed for this study was based on the three components of attitude theory; cognitive, affective, and behavior (Triandis, 1971; Ma'arif, Abdullah, Fatimah, \& Hidayati, 2021). The data analysis included the following activities: 1) Data condensation, selecting data chunks to strengthen the data. 2) Data display, creating matrix display to present complete data set in the exact location and 
arranged systematically. 3) Conclusion drawing and verification interpreting the findings to create a conclusion.

\section{FINDINGS AND DISCUSSION}

Three emergent themes are present to answer the research question, what is the Indonesian pre-service teachers' attitude towards Thai English during a five-month teaching practicum in Thailand? Those are 1) Lack of intelligibility of Thai English, 2) emotional shift experiences and hybridity of Thai and English. More detailed elicitation is outlined subsequently:

\section{Lack of Intelligibility of Thai English}

Lack of intelligibility of Thai English is the first empirical evidence discovered when the participants dealt with Thai students' English pronunciation. To illustrate, most of them highlighted their Thai English accents, which made it difficult to comprehend what those Thai students verbalized. Viewed from the cognitive component of attitudes, most participants perceived that Thai English was hard to understand. P1 uttered, Thai English accent was "hard to understand" so he could not comprehend what the speakers were saying. Furthermore, P2 expressed, "their accent was also kind of hard to understand for me", she could not always understand Thai English speakers because sometimes she found herself did not get the point of the utterances. Different from other participants, $\mathrm{P}_{3}$ mentioned, "Thai students didn't understand what I was saying". Her students did not understand her speech. Moreover, P4 reported, "I could not notice her English". He was not familiar with English uttered by Thai English speakers and fell not to understand. Those participants also informed that the difference in pronunciation primarily caused the difficulty in understanding Thai English speakers:

P1: “...Some words or some sounds are different with us... at the first is kind of weird maybe for the first time like 'what did they say?' I could not understand it"

P2: "...sometimes there was different pronunciation made me sometimes understand sometimes I don't."

P3: "As I arrived at the class and I observed, and wow, the fact that their [Thai English speakers] pronunciation was like this, and it was funny for me at the first time 'why is it like this maybe it was their characteristic.

P4: “...there are two letters they cannot pronounce well for example /v/ became /w/ 'how's your life and they said 'wery wew huh 'wery wew'? /l/ becomes /n/ sometimes, for example, 'I will go to schoon'..."

As P1 mentioned, 'some sounds are different' and stated that it was weird, resulting in him not understanding what Thai English speakers said. Furthermore, P2 expressed that some words were differently pronounced by Thai English speakers and confused her to understand them. In addition, P3 mentioned the utterance of the word of Thai English speakers was 'funny.' Moreover, the data above showed that $\mathrm{P} 4$ noted Thai English features. He revealed that Thai English substituted some English consonants, which made him hard to catch.

Most participants agreed that they had a problem understanding Thai English speakers because they could not recognize English words uttered. According to the definition of 'understanding' in the interaction between speaker and listener by Smith and Nelson (2020), the recognition of words and sentences from speakers' utterances is called 'intelligibility'. From the explanation, it can be inferred that participants assumed that Thai English lacks intelligibility. They also believed that the difference in Thai English pronunciation caused difficulty in understanding Thai English speakers. Since the interaction took place at an International program, as Kirkpatrick (2007) stated, English in one region or country may sound and look very different from the language (cited in Nelson, 2011; Hidayati, 2018). In addition, according to Blake et al. (2019), English pronunciation varieties may be influenced by home language and impact the intelligibility in English. 
Moreover, the Thai English system studies indicated that Thai English rhythm and vowels were strongly influenced by the substrate Thai resulting in Thai English is distinctive from native English (Sarmah, Gogoi, \& Wiltshire, 2009). The Thai language affected how Thai English speakers pronounce English words, which led the participants not to understand it. Bautista and Gonzales (1996) suggest that even though 99\% of the students in Thailand learn English at schools, not many succeed in acquiring much English proficiency. Moreover, Sarmah, Gogoi, and Wiltshire (2008) mention, "pronunciation was rarely the focus of instruction" (p. 198).

\section{Emotional Shift Experiences}

Another finding showcased emotional shift experiences. All participants felt that their emotions changed dynamically when interacting with their students, such as worry, shock, exasperation, and surprise. These phenomena were categorized as a part of the affective component of attitude.

The questions concerning emotion in interacting with Thai English speakers were given to the participants to examine the affective component of attitude during the ITP program for six months. The results indicated that complete participants held negative attitudes while interacting with Thai English speakers at the beginning and shifted to positive attitudes.

\section{P1: "more to feel worried" \\ P2: "Kind of shocked" \\ $P_{3}$ : "sometimes I felt exasperated" \\ P4: "I was very surprised"}

The interview showed that the fear experienced by P1 led him to be unable to respond to the students. This could decrease his students' desire to communicate with him. In addition, P2 expressed that she was worried that her limited ability to communicate with Thai English speakers could bring misunderstanding. Moreover, she stated that she was pessimistic about surviving in the ITP program. Likewise, $\mathrm{P}_{3}$ felt exasperated and sad when a Thai English speaker could not understand what she meant then fell to miscommunication. In addition, $\mathrm{P} 4$ mentioned that he was surprised when communicating with Thai English speakers because he could not notice their English words. Nevertheless, as time passed by, the result showed that participants experienced emotional shifts. Then they tended to have a positive attitude since they could overcome their difficulty in communicating with Thai English speakers. P1 uttered, "I felt relieved." Further, P2 mentioned, "I felt enjoyed, felt like I had no burden." Moreover, P4 shifted to more positive feelings, "I felt more comfortable and I felt more confident".

Having more language contact with American and British English as inner-circle varieties is one reason for holding a negative cognitive attitude towards Thai English, which they were not familiar with. According to Munro et al. (2006), Inner Circle Englishes were always more intelligible than others. People tend to work hard at understanding non-Inner Circle varieties of English and are more likely to exhibit prejudice towards them. The recent study was similar to Ahn (2015) reporting that Korean and foreign English teachers who had a problem in understanding Asian Englishes used in Singapore, India, China, and Japan and inability to communicate with Asian English speakers leading them to have a negative attitude toward Asian English in their experience going to overseas.

Unsuccessful communication experienced by participants led them to hold negative emotions towards Thai English speakers. In line with Ahn (2015), experiencing a problem in understanding Asian Englishes resulted in frustration. However, familiarity with a variety of English speakers plays a crucial role in understanding interlocutors. As Nelson (2020) mentioned, one has more familiarity with speakers of different English varieties, either native or non-native speakers. Becoming familiar with Thai English during the ITP program led participants' negative emotions to shift to positive ones. Briefly stated, an English teacher should be able to contextually position himself/herself to the encountered classroom situations and students' attitudes to be accepted by students. With this in 
mind, students' engagement can be maintained while performing classroom teaching practices (Rianti, Hidayati, Pertamana, Andriani, \& Abdullah, 2020).

The result of the recent study is similar to Shim (2002) identifying the attitude changes of the Korean people toward English varieties. The result showed that at first watching non-native English speakers, they could not understand what he was saying, resulting majority of Korean people were not ready to accept his speech. However, there were more favorable responses to non-native Englishes and a significant awareness increase of English varieties slowly. Therefore, this enables teachers to promote students' critical language awareness when communicating with English (Hidayati, Mohnawawi, \& Ramdhani, 2019).

\section{The Hybridity of Thai and English}

The last fact generated from the data analysis results is that Thai English is viewed as a hybridity of Thai and English. For instance, the participants performed code-mixing and codeswitching (English and Thai) when teaching English to their students. This was conducted due to the Thai students' inability to comprehend English fully. They acknowledged that teaching English to Thai students requires them to develop and enrich their insights towards the Thai language and cultures (e.g., learning Thai to facilitate them communicate to their Thai students). This occurrence was classified as the behavioral component of attitude. The entire participants showed positive attitudes, and there was no rejection of the use of Thai English. Moreover, they learned the Thai language to overcome their limited access in communicating with Thai English speakers.

\section{P4: “... I overcome this [difficulty to communicate with Thai English speakers] by learning Thai from anyone, from kids, my colleges ... I cannot force them to speak English that's why I decided to learn the Thai language very hard or seriously..."}

In addition, it was also pointed out that the vocabulary learned by participants was used when using English. For example, P1 stated that he spoke 'okay mai?', mai means 'not'. This short interrogative sentence is an agreement expression like 'is it ok or not?'. Moreover, P2 mentioned that she mixed Thai vocabulary and English when communicating with Thai English speakers. Further, P3 uttered that she used Thai language and English to explain the materials to her students while teaching. And P4 used the word 'lin' as the Thai language mixed with football as the English word, he said 'lin football'.

\section{P1: "for example, I said 'Ok mai?' mai means not, and I used 'riyan' means studying and 'sedlew mai?' means have you finished" \\ P2: "So also mixed [Thai language and English]" \\ $P_{3}$ : "When I explained the materials I mixed with the Thai language." \\ P4: "I said 'lin football' means play football."}

Furthermore, in the classroom situation, the result noticed that the entire participants did not force students not to use Thai English, and surprisingly, they used English mixed with Thai to have clear instruction. As uttered by P1, though, as an English teacher, he wanted his students to pronounce 'veh' sound. However, he understood their condition. Thus he did not force his students to pronounce it properly, and he accepted their way of pronouncing English words. Moreover, P2 reported that she learned Thai and used it in teaching-learning activities. It can be indicated that she was welcome to Thai English even in the classroom. In addition, $\mathrm{P}_{3}$ stated that she learned Thai to adapt with her students because she believed it was necessary to use students' native language for teaching.

P1: $\quad$ "As a teacher, I want [my students] able to pronounce some sounds, for example, able to pronounce 'veh'. But I didn't make it as a reason to force 
them, because I understand their condition. They already learn about it, but at the end they still [use their way to pronounce it]"

\section{P2 "Day by day my Thai vocabulary increased and I could use it in the instructional process." \\ $P_{3}: \quad$ "When we are teaching without [students' native language] is difficult, whether I want it or not, I have to learn it."}

To overcome problems in understanding Thai English speakers, all participants decided to learn the Thai language. What they have acted is called convergence. Referring to Ogay \& Barbara (2005), convergence is defined as a strategy where individuals adapt their communicative behaviour in such a way as to become more similar to their interlocutor's behaviour. For example, they used lexical items from the Thai language in speaking English like 'Ok mai'. This is included in the Thai English feature called 'Hybridization'. The Thai English user put Thai lexical items when using English (Watkhaolarm, 2005). It can be concluded that the participants spoke Thai English.

In sum, learning the Thailand language to overcome problems in understanding Thai English speakers instead of forcing Thai students to use English like native means the participants held a positive behavioral attitude. According to Ahn (2015), the international experiences and experiences of being unable to communicate with Asian Englishes are likely to have more positive attitudes toward English varieties than those who do not. Teachers' attitudes toward Asian English have been examined (Tandiana, Abdullah, Komara, 2018). Ahn (2014), in South Korea, conducted a study into the attitudes of English teachers, either Korean or non-Korean, toward Korean English regarding behavioral component of attitude varied. The result showed that the overwhelming majority of participants reported a negative attitude toward the implication of Koran English in the classroom, yet reported a positive attitude toward using Korean English by others for communication.

\section{CONCLUSION}

The present study examines the Indonesian pre-service teachers' attitudes towards Thai English amid their teaching practicum in Thailand. The findings reported that the Indonesian preservice teachers' attitudes to Thai English were lack of intelligibility, emotional shift experiences and hybridity of Thai and English. These attitudes represent cognitive, affective, and behavioral components while participating in Thailand's International Teaching Practicum program (ITP program). Cognitively, they enable to extend their knowledge about English language varieties, especially Thai English (e.g., lexical choices, syntactical features, sociopragmatic meanings and discourse orientations). Affectively, they undergo a significant paradigmatic shift where successful communication in English does rely on accentedness but mutual intelligibility. Behaviourally, they become aware that English does not only refer to its native speakers (the inner circle) but also outer and expanding circles in which non-native speakers of English outnumber native speakers. With these in mind, the way how to view non-native speakers of English, a typical English variety (e.g., Thai English), and English language teaching and learning practices can be adjusted to the backgrounds of the language users viewed from their identities, cultures, beliefs, attitudes, and sociohistory. The pre-service teachers' awareness to maintain their backgrounds and appreciate English as the non-native language (English as a second language and English as a foreign language) can be established. Equally important, this enables to mitigate the native speakers fossilized in the paradigm of the non-native speakers of English. Hence, mutual intelligibility becomes the ultimate goal of communication.

Though this study provides valuable contributions, it indicates some limitations. First, the present study only deployed a sole data collection technique, namely semi-structured interview. Future studies should involve various data collection techniques as a manifestation of triangulation (e.g., document analysis, questionnaire administration, and observation). Second, the participants of this study were only recruited from Indonesia. Further studies should embrace other participants, 
such as those from Thailand, where Thai English is widely used and native speakers of English to explore the notion of mutual intelligibility from their perspectives. Lastly, this study merely deployed a descriptive case study to portray the investigated phenomena and participants comprehensively. Future studies can utilize a survey to cover more participants and a holistic description of participants' attitudes.

\section{REFERENCES}

Abdullah, F., \& Lulita. (2018). Social actors in an intercultural communication classroom: A discursive lens of intercultural education. IJELT, 13(1), 31-51.

Ahn, H. (2014). Teachers' attitudes towards Korean English in South Korea. World Englishes, 33(2), 195-222. https://doi.org/10.1111/weng.12081

Ahn, H. (2015). Awareness of and attitudes to Asian Englishes: a study of English teachers in South Korea. Asian Englishes, 17(2), 132-151. https://doi.org/10.1080/13488678.2015.1036602

Andriani, A., \& Abdullah, F. (2017). Invigorating the EFL students in acquiring new linguistic knowledge: Language learning through projects. Proceedings of the 4th international language and language teaching conference, Nov 2017, (pp. 1-15). Yogyakarta: English Language Education Study Program, Sanata Dharma University.

Blake, H. L., Verdon, S., \& McLeod, S. (2019). Exploring multilingual speakers' perspectives on their intelligibility in English. Speech, Language and Hearing, $O(0)$, 1-12. https://doi.org/10.1080/2050571X.2019.1585681

Bolton, K., \& Kachru, B. B. (2006). World Englishes: Critical Concepts in Linguistics - Google Books. Retrieved January 14, 2020, from Routledge website:https://books.google.co.id/books?hl=en\&lr=\&id=9yT33ebcOBkC\&oi=fnd\&pg=PR8\& $\mathrm{dq}=\mathrm{kachru}+$ world + englishes\&ots $=\mathrm{bNDv1sQocF} \& \operatorname{sig}=\mathrm{dXYMwxCVJ} 4 \mathrm{uC} \_$ya9EQVT3rV3EDA\& redir_esc $=\mathrm{y} \# \mathrm{v}=$ onepage $\& \mathrm{q}=$ inner\&f$=$ false

Chamcharatsri, P. B. (2013). Perception of Thai English. English as an International Language, 8(1), 21-36. https://doi.org/10.1093/elt/ccio64

Curran, J. E., \& Chern, C. lan. (2017). Pre-service English teachers' attitudes towards English as a lingua franca. Teaching and Teacher Education, 66, 137-146. https://doi.org/10.1016/i.tate.2017.04.007

Crystal, D. (2012). English as a global language. Cambridge university press, 1-41.

Dwyer, E. E. (1993). Attitude Scale Construction: A Review of the Literature. Educational Resources Information Center, 1-45.

Garrett, P. (2010). Attitudes to language. Cambridge University Press. Retrieved from https://books.google.co.id/books?hl=en\&lr=\&id=BdAE2ZnBfocC\&oi=fnd\&pg=PR1\&ots=Wjc ILZ2FEB\&sig=G17R4hcTmAXvKXZ2PoZpVD3MwI4\&redir esc =y\#v=onepage\&q\&f=false

Hamid, M. O., Hoang, N. T. H., \& Nguyen, T. T. T. (2021). Changing teacher learners' language ideologies and pedagogical practices: an action research intervention in World Englishes. Asian Englishes, 1-18.

Heigham, J., \& Croker, R. (Eds.). (2009). Qualitative research in applied linguistics: A practical introduction. Springer.

Hidayati, A. N. (2018). Falling into Culturist Trap: Practice of Othering in An Indonesian English Language Classroom. Jurnal Penelitian Humaniora, 19(1), 1-9.

Hidayati, A. N., Mohnawawi, B., \& Ramdhani, R. (2019). Narrating students'identity to promote critical language awareness. Getsempena English Education Journal, 6(1), 23-33.

Hidayati, A. N., \& Santiana, S. (2020). Promoting cultural awareness through intercultural listening activities. Jurnal Tahuri, 17(2), 53-62.

Hidayati, A. N., Dewi, N. S. N., Nurhaedin, E., \& Rosmala, D. (2020). Foreign Language Listening Anxiety in an Academic Listening Class. J-SHMIC: Journal of English for Academic, 7(2), 1-9.

Ives, P. (2019). Gramsci and "Global English" 1. Rethinking Marxism, 31(1), 58-71. https://doi.org/10.1080/08935696.2019.1577617

Jenkins, J. (2007). English as a lingua franca: Attitude and identity. Oxford: Oxford University Press.

Jenkins, J., Cogo, A., \& Dewey, M. (2011). Review of developments in research into English as a lingua franca. Language teaching, 44(3), 281-315. 
Kachru, B. B. (1992). World Englishes: Approaches, issues and resources. Language teaching, 25(1), 1-14.

Kachru, Y., \& Nelson, C. L. (2006). World Englishes in Asian Contexts (Vol. 1). Hongkong: Hong Kong University Press.

Kim, S. (2018). Development of discursive practices for the intelligibility of Thai English in interaction: Sequence and categories as contextual resources. System, 72, 164-177. https://doi.org/10.1016/j.system.2017.12.005

Kirkpatrick, A. (2007). World Englishes Paperback with Audio CD: Implications for International ... - Andy Kirkpatrick - Google Books. Retrieved January 14, 2020, from https://books.google.co.id/books?hl=en\&lr=\&id=nOH3V6MYZh8C\&oi=fnd\&pg=PR8\&dq=Ki rkpatrick,+A.+(2007).+World+Englishes+paperback+with+audio+CD:+Implications+for+int ernational+communication+and+english+language+teaching.+Cambridge+University+Press. \&ots $=$ inkLo1ie $4 \mathrm{~m} \& \operatorname{sig}=0$

Lee, J. S., Lee, K., \& Arifah Drajati, N. (2019). Pre-service English teachers' perceptions of English as an international language in Indonesia and Korea. Journal of Multilingual and Multicultural Development, 4O(3), 230-243. https://doi.org/10.1080/01434632.2018.1503669

Lim, S. (2020). A critical analysis of Cambodian teachers' cognition about World Englishes and English language teaching. Asian Englishes, 22(1), 85-100.

Ma'arif, A. S., Abdullah, F., Fatimah, A. S., \& Hidayati, A. N. (2021). Portfolio-Based Assessment in English Language Learning: Highlighting the Students' Perceptions. J-SHMIC: Journal of English for Academic, 8(1), 1-11.

Marlina, R. (2017). Teaching English as an International Language: Implementing, reviewing, and re-envisioning World Englishes in language education. Routledge: Oxfordshire, England, UK.

McIntosh, M. J., \& Morse, J. M. (2015). Situating and constructing diversity in semi-structured interviews. Global Qualitative Nursing Research, 2. https://doi.org/10.1177/23333393615597674

McKenzie, R. M. (2010). The social psychology of English as a global language: Attitudes, awareness and identity in the Japanese context (Vol. 10). Springer Science \& Business Media.

Miles, M. B., Huberman, A. M., \& Saldaña, J. (2014). Qualitative Data Analysis: A Methods Sourcebook (Third). SAGE Publications.

Munro, M. J., Derwing, T. M., \& Morton, S. L. (2006). The mutual intelligibility of L2 speech. Studies in second language acquisition, 111-131.

Ogay, T., \& Barbara, S. (2005). Communication accommodation theory: A look back and a look ahead Communication Accommodation Theory : A Look-Back and a Look Ahead Cindy Gallois The University of Queensland Tania Ogay The University of the Geneva Howard Giles University of California at San. (May 2014).

Rajprasit, K. (2021). 'Do as WE Do': Teaching World Englishes in a General English Course to Thai Students. RELC Journal, o0336882211011276.

Rezaei, S., Khosravizadeh, P., \& Mottaghi, Z. (2019). Attitudes toward World Englishes among Iranian English language learners. Asian Englishes, 21(1), 52-69. https://doi.org/10.1080/13488678.2018.1440367

Rianti, A., Hidayati, A. N., Pertamana, D., Andriani, A., \& Abdullah, F. (2020). Profiling an ideal teacher. Koli Journal, 1(2), 65-74.

Sadeghpour, M., \& Sharifian, F. (2017). English language teachers ' perceptions of world Englishes : the elephants in the room English language teachers ' perceptions of world Englishes : Asian Englishes, 8678, 1-17. https://doi.org/10.1080/13488678.2017.1362782

Sarmah, P., Gogoi, D. V., \& Wiltshire, C. (2009). Thai English: Rhythm and vowels. English WorldWideEnglish World-Wide. A Journal of Varieties of English, 30(2), 196-217. https://doi.org/10.1075/eww.30.2.05sar

Shim, R. J. (2002). Changing attitudes toward TEWOL in Korea. Journal of Asian Pacific Communication, 12(1), 143-158.

Sirivedin, P., Soopunyo, W., Srisuantang, S., \& Wongsothorn, A. (2018). Effects of Facebook usage on English learning behaviour of Thai English teachers. Kasetsart Journal of Social Sciences, 39(2), 183-189.

Smith, L. E., \& Nelson, C. L. (2019). World Englishes and issues of intelligibility. The handbook of 
world Englishes, 430-446.

Smith, L. E., \& Nelson, C. L. (2020). 24 World Englishes and Issues of Intelligibility. In L. C. Nelson, G. Z. Proshina, \& R. D. Davis (Eds.), World Englishes and issues of intelligibility (second, pp. 431-445). https://doi.org/https://doi.org/10.1002/9781119147282.ch24

Snodin, N. S., \& Young, T. J. (2015). "Native-speaker" varieties of English: Thai perceptions and attitudes. Asian Englishes, 17(3), 248-260. https://doi.org/10.1080/13488678.2015.1083354

Susam-Sarajeva, Ş. (2009). The case study research method in translation studies. Interpreter and Translator Trainer, 3(1), 37-56. https://doi.org/10.1080/1750399X.2009.10798780

Taguchi, N., \& Ishihara, N. (2018). The pragmatics of English as a lingua franca: Research and pedagogy in the era of globalization. Annual Review of Applied Linguistics, 38, 80-101.

Tamimi Sa'd, S. H. (2018). World English and World Englishes: perspectives from English language learners in Iran. Journal of World Languages, 5(1), 23-45. https://doi.org/10.1080/21698252.2018.1500151

Tandiana, S. T., Abdullah, F., Komara, U., (2018). Talk- Write: A groundbreaking technique for shaping the students' argumentative writing skills on discussion essays. EEAL Journal (English Education and Applied Linguistics Journal), 1(1), 1-9.

Tarrayo, V. N., Ulla, M. B., \& Lekwilai, P. (2020). Does Thai English exist? Voices from English language teachers in two Thai universities. Asian Englishes, 1-14. https://doi.org/10.1080/13488678.2020.1821299

Trakulkasemsuk, W. (2018). English in Thailand: looking back to the past, at the present and towards the future. Asian Englishes, 2O(2), 96-105. https://doi.org/10.1080/13488678.2017.1421602

Tsukada, K. (2008). An acoustic comparison of English monophthongs and diphthongs produced by Australian and Thai speakers. English World-WideEnglish World-Wide A Journal of Varieties of English, 29(2), 194-211. https://doi.org/10.1075/eww.29.2.05tsu

Tsukada, K. (2009). Durational characteristics of English vowels produced by Japanese and Thai second language (L2) learners. Australian Journal of Linguistics, 29(2), 287-299. https://doi.org/10.1080/07268600902823144

Wall, U. (2008). Innovation in Language Learning and Teaching A Needs Assessment Interview : The Professional Development Needs of Non- native Speaking EFL Teachers in Thailand A Needs Assessment Interview : The Professional Development Needs of Non-native Speaking EFL Te. (February 2013), 37-41. https://doi.org/10.2167/illto28.

Wang, X., Jiang, L., Fang, F., \& Elyas, T. (2021). Toward critical intercultural literacy enhancement of university students in China from the perspective of English as a lingua franca. Sage Open, 11(2), 21582440211027544.

Watkhaolarm, P. (2005). Think in Thai, write in English: Thainess in Thai English literature. World Englishes, 24(2), 145-158. https://doi.org/10.1111/j.1467-971X.2005.00399.X 